\title{
Small for Gestational Age for Length
}

National Cancer Institute

\section{Source}

National Cancer Institute. Small for Gestational Age for Length. NCI Thesaurus. Code C118699.

Birth length greater than two standard deviations below the mean for the reference population of the same sex and gestational age. 